\title{
Religious non-governmental organizations and philanthropy in Indonesia
}

\author{
Tuti Alawiyah
}

Social Welfare Department, Universitas Islam Negeri Jakarta E-mail:tuti_alawiyah@uinjkt.ac.id

\begin{abstract}
Religious non-governmental organizations (RNGOs) and philanthropic activities in Indonesia have a long history. They existed prior to the creation of the nation state. Social, political and economic changes in this country have influenced the development of non-profit organizations for more than sixty years after the Independence of the Republic Indonesia in 1945. Modernization and development projects during the President Suharto era influenced the development of Nongovernmental organizations (NGOs). In more recent years, RNGOs have largely developed as a response to the socio-economic crisis after the downfall of President Suharto regime. Discovering the dynamics of RNGOs in a broader context of non-profit organizations in Indonesia provides insights into the strengths and weaknesses of philanthropic activism in recent years. An historical overview of non-profit organizations, legal structures, functions, and financial resources are among the themes that are described in this paper.
\end{abstract}

Organisasi Agama Non Pemerintah (RNGOs) dan kegiatan filantropi di Indonesia memiliki sejarah yang panjang. Mereka ada sebelum penciptaan negara bangsa. Perubahan sosial, politik dan ekonomi di negara ini telah memengaruhi perkembangan organisasi nirlaba selama lebih dari enam puluh tahun setelah 
Kemerdekaan Republik Indonesia pada tahun 1945. Modernisasi dan pembangunan proyek-proyek selama era Presiden Soeharto memengaruhi perkembangan organisasi non-pemerintah (LSM). Dalam tahun-tahun terakhir, RNGOs sebagian besar telah dikembangkan sebagai tanggapan terhadap krisis sosial-ekonomi setelah jatuhnya rezim Presiden Soeharto. Menemukan dinamika RNGOs dalam konteks yang lebih luas dari organisasi nirlaba di Indonesia memberikan wawasan ke dalam kekuatan dan kelemahan dari aktivisme filantropi dalam beberapa tahun terakhir. Sebuah gambaran sejarah organisasi non-profit, struktur hukum, fungsi, dan sumber daya keuangan adalah salah satu tema yang dijelaskan dalam makalah ini

Keywords: Non-profit organizations; Religious NGOs (RNGOs); Philanthropy; Indonesia

\section{Introduction}

Understanding religious non-governmental organizations (RNGOs) and philanthropic activities in Indonesia reflects how nonprofit organizations and philanthropic activities are influenced by religion in Indonesian Muslim Society. Candland ${ }^{1}$ points out that Islamic faith in Indonesia has been a source of social formation in building religious nonprofit organizations. The Muhammadiyah - the second largest religious organization - is the best example of a nonprofit organization that has applied Islamic belief as its basis. In addition, this organization has made use of Muslim philanthropy to expand its programs mainly on community development, education and health services. The Dompet Dhuafa Foundation (literally means Wallet of the Poor) -often abbreviated as "DD" is another example of how RNGOs have utilized local philanthropy to operate programs on education, health services, and micro finance. This paper attempts to understand the strengths and weaknesses of

\footnotetext{
${ }^{1}$ C.Candland, Faith as Social Capital: Religion and Community Development in Southern Asia, Policy Sciences, 33 (2000), 355-374.
} 
religious non-governmental organizations by describing their historical development, functions, financial resources and legal structures. Furthermore, this article will position religious NGOs within a broader context of Indonesian nonprofit organizations and civil society. This article is divided into three parts. The first part begins with a definition of NGOs and RNGOs, an overview of previous studies, and an historical development of nonprofit organizations in Indonesia. The second part is a description of the legal structures, functions, and financial issues that face religious and secular non-profit organizations in Indonesia today. The third part offers conclusion and recommendation for future studies.

\section{NGOs and RNGOs}

The term "NGOs" in this article will be used interchangeably with other similar terms, namely, third sector organizations and non-profit organizations. As mentioned by Martens, ${ }^{2}$ NGOs can refer to any organization that has certain characteristics: is non-profit or voluntary, is nonviolent in character, does not rely on government financial and moral support, is free from any interventions, and can be operated at national, regional and international levels. While the term NGO has been widely used, the term RNGO, according Julia Berger, ${ }^{3}$ is quite new and is sometimes used interchangeably with the term faith-based organization. Berger, ${ }^{4}$ following Martens' definition for NGO, defined RNGOs as "formal organizations whose identity and mission are self-consciously derived from the teachings of one or more religious or spiritual traditions and which operates on a non-profit, independent, voluntary basis

${ }^{2}$ K. Martens, "Mission Impossible? Defining Nongovernmental Organizations", Voluntas, Vol. 13, No. 3 (September 2002), 271-285.

3 Julia Berger, "Religious NGOs: an Exploratory Analysis", Voluntas, Vol. 14, No. 1 (2003), 1539. 
to promote and realize collectively articulated ideas about the public good at the national or international level". Berger mentioned that RNGOs such as World Vision, the Salvation Army, and Catholic Relief Servicesare different from religious organizations such as congregations and denominations that "seek to fulfil explicitly public missions". Furthermore, Berger argued that even though the influence of RNGOs and religious actors in public life was not new, this field "has been largely ignored."

Applying Berger's RNGOs definition, ${ }^{5}$ there are several Indonesian organizations that can be classified as RNGOs. Religious philanthropic organizations such as the Dompet Dhuafa Foundation, the PKPU (the National Humanitarian Foundation) and Rumah Zakat Indonesia (Humanitarian and Charitable Foundation) are religious NGOs that are based on Islamic beliefs. Their goals and programs are to fulfil the public good at the national level. These religious non-profit organizations collect and manage Muslim donations such as zakat, sedekah, hibah, infak, and wakaf. ${ }^{6}$ These organizations have taken deliberate steps to identify themselves as "religious" in order to reach more Muslim donors. They contend that such displays of Islamic beliefs and values will provide them with public legitimacy in the field. Al-Falah Social Funds Foundation and the PKPU, for example, have Islamic teaching programs (Pengajian and $d a^{\prime} w a h$ ) addressing both Muslim donors and recipients.

Several studies on NGOs in Indonesia have been done.7 However, these studies have not specifically addressed religious non-profit organizations. Prijono, for example, assesses organized private philanthropy

${ }^{4}$ Julia Berger, "Religious NGOs: an Exploratory Analysis"..., 15-39.

${ }^{5}$ Julia Berger, "Religious NGOs: an Exploratory Analysis"..., 2.

${ }^{6}$ Chaider S. Bamualim, Islamic Philanthropy \& Social Development in Contemporary Indonesia, Jakarta: Center for the Study of Religion and Culture, State Islamic University Syarif Hidayatullah, 2006.

7 O. S. Priyono, "Organized Private Philanthropy in Indonesia", in Baron, B. F. (ed.), Philanthropy and the Dynamics of Change in East and Southeast Asia", Occasional papers of the East 
in general including religious institutions, social welfare organizations, and social organizations. Feulner examines the relationship between civil society organizations and the state in consolidating the democratization process. ${ }^{8}$ The Synergos Institute reports a national directory of civil society resource organizations in Indonesia including NGOs. ${ }^{9}$

Other studies such as PIRAC and Chaidir and Abubakar mention the current phenomenon of religious philanthropic organizations, but these case studies are descriptive and not placed in the context of non-profit organizations and the popular crusade to improve civil society in Indonesia. ${ }^{10}$ The most recent case study conducted by Saidi, et. al. (2006) mention the new phenomenon of corporate and religious philanthropy, but it does not emphasize religious philanthropic organizations and is limited to the case of the Dompet Dhuafa Foundation. ${ }^{11}$

\footnotetext{
Asian Institute, Columbia University, New York: East Asian Institute, 1991, 127-139; M. Johnson, "Non-government Organizations at the Crossroads in Indonesia", in Rice, R. C. (ed.), Indonesian Economic Development: Approaches, Technology, Small-Scale Textiles, Urban Infrastructure and NGOS, Victoria: Centre of Southeast Asian Studies, Monash University, Clayton, 1990; The Synergos Institute. National Directory of Civil Society Resource Organizations, Indonesia. Series on Foundation Building in Southeast Asia. The Synergos Institute, New York; http:// www.synergos.org/globalphilanthropy/02/indonesiacsrodirectory.pdf. 2002; F. Feulner, Consolidating Democracy in Indonesia: Contributions of Civil Society and State. Part one : Civil Society. Working paper series, Jakarta: UNSFIR, 2001; Public Interest Research and Advocacy Center (PIRAC) (Indonesia), \& Asian Development Bank. Giving and Fund Raising in Indonesia: Investing in Ourse/ves. Manila, Philippines: Mandaluyong City, Metro, 2002; Zaim Saidi, M. Fuad, and H. Abidin. Social Justice Philanthropy in Indonesia. Depok, Indonesia: Piramedia, 2006.

${ }^{8}$ F. Feulner, Consolidating Democracy in Indonesia: Contributions of Civil Society and State. Part one : Civil Society. Working paper series, Jakarta: UNSFIR, 2001.

${ }^{9}$ The Synergos Institute. National Directory of Civil Society Resource Organizations, Indonesia. Series on Foundation Building in Southeast Asia. The Synergos Institute, New York; http:// www.synergos.org/globalphilanthropy/02/indonesiacsrodirectory.pdf. 2002.

${ }^{10}$ Public Interest Research and Advocacy Center (PIRAC) (Indonesia), \& Asian Development Bank. Giving and Fund Raising in Indonesia: Investing in Ourselves. Manila, Philippines: Mandaluyong City, Metro, 2002.

${ }^{11}$ Zaim Saidi, M. Fuad, and H. Abidin. Social Justice Philanthropy in Indonesia. Depok, Indonesia: Piramedia, 2006.
} 
From the limited body of literature on NGOs, researchers have argued that financial difficulties are a shared problem for most NGOs in Indonesia. They have found that these NGOs rely on funding from international donors. The Synergos Institute, for example, mentions that among the 25 Indonesian CSROs that were surveyed in their study, only one religious philanthropic organization has been able to subsist without foreign aid. ${ }^{12}$ The Dompet Dhufa Foundation has utilizes nearly 100 percent of domestic resources from individual donations and corporate sectors. As a result, researchers point to a need to strengthen philanthropic activities within NGOs by diversifying local resources and building relations with corporate sectors. ${ }^{13}$ Therefore, addressing the strengths and weaknesses of religious NGOs in terms of their historical development, social functions and financial resources may contribute to broaden people's knowledge on non-profit organizations in Indonesia.

\section{Historical evolution of RNGOs in Indonesia}

First Phase

In the first phase, the development of non-profit organizations and philanthropic activities can be traced back to the history of the forma-

12 The Synergos Institute. National Directory of Civil Society Resource Organizations, Indonesia. Series on Foundation Building in Southeast Asia. The Synergos Institute, New York; http:/ /www.synergos.org/globalphilanthropy/02/indonesiacsrodirectory.pdf. 2002.

${ }^{13}$ D. Winder, "Civil Society Resources Organizations (CSROs) and Development in Southeast Asia", A summary of findings, Series on Foundation Building in Southeast Asia, The Synergos Institute, New York, 1998; Hasan, S. \& Onyx, J., "Governance Approach in Asia's Third Sector: Adapted Western or Modified Asian?", in Hasan, S. \& Onyx, J. (eds.), Comparative Third Sector Governance in Asia. Springer, New York, 2008, 193-205; F. Feulner, "Consolidating Democracy in Indonesia: Contributions of Civil Society and State. Part one : Civil Society", Working paper series, Jakarta: UNSFIR, 2001; The Synergos Institute. National Directory of Civil Society Resource Organizations, Indonesia. Series on Foundation Building in Southeast Asia. The Synergos Institute, New York; http://www.synergos.org/globalphilanthropy/02/indonesiacsrodirectory.pdf. 2002. 
tion of the Republic of Indonesia in 1945. During this era, Indonesian leaders focused their concerns on social issues such as education, health and religious matters. They recognized that education was important for ordinary people who did not have access to public school during the colonial administration. These social and religious leaders then established organizations such as the Boedi Oetomo (an organization focused on education, art, and culture), the Sarekat Islam (an organization focused on trade and religious matters), and the Muhammadiyah (an organization focused on education and health). ${ }^{14}$

Regarding philanthropic activities, millions of Indonesian people voluntarily worked during the Revolution war period to help soldiers and war's victims, provided shelters and medical emergency services. After the Independence, people continued to practice traditional philanthropy by supporting other poor people in their families and neighborhoods as well as supporting religious organizations such as the Muhammadiyah, the $\mathrm{NU}$, pesantrens (Islamic boarding schools), orphanages, and mosques.

Among religious organizations, the Muhammadiyah has utilized Muslim philanthropy such as zakat (compulsory giving) and sedekah, hibah, infak, and wakaf (voluntary giving) to support executing the programs of the organization. The Muhammadiyah has started its services to provide education and health services since its early establishment. The first modern school started six years after its formal establishment in 1912 and the first health clinic started a decade later in 1923. The existence of the Muhammadiyah as a religious non-profit organization has continued until now with thousands of schools from kindergarten to higher education, with hundreds of orphanages, clinic centres and hospitals throughout the country. ${ }^{15}$

\footnotetext{
14 Zaim Saidi, M. Fuad, and H. Abidin, Social Justice Philanthropy in Indonesia..., 4.

15 Zaim Saidi, M. Fuad, and H. Abidin, Social Justice Philanthropy in Indonesia..., 4.
} 
It is important to note that the establishment of religious non-profit organizations was not exclusive to the Muslim community in Indonesia during the pre-Suharto era. Other religious communities developed similar religious organizations as well. For instance, the Lembaga Daya Darma (LDD) in Jakarta managed donations from Catholic Churches and the Yadna Puniakerti in Surabaya managed funds from Hindu Temples.

\section{Second phase}

The second phase is the New Order era, which began when the former President Suharto came to power. Several non-governmental organizations were established during this era. ${ }^{16}$ As mentioned by Johnson, among the big thirteen NGOs that were established in this period are: PKBI (focused on family planning and community development), Yayasan Dian Desa (an organization focused on applied technology and rural development), LP3ES (a research center for education, social, economy), P3M (an organization for community development through Muslim institutions) and WALHI (Indonesian Forum for Environment). ${ }^{17}$ In contrast to earlier NGOs, the Suharto era witnessed the rise of organizations that rely heavily on international funding ${ }^{18}$ and

\footnotetext{
${ }^{16}$ M. Johnson, "Non-government Organizations at the Crossroads in Indonesia", in Rice, R. C. (ed.). Indonesian Economic Development: Approaches, Technology, Small-Scale Textiles, Urban Infrastructure and NGOs. Monash University, Clayton, Victoria: Centre of Southeast Asian Studies, 1990; The Synergos Institute. National Directory of Civil Society Resource Organizations, Indonesia. Series on Foundation Building in Southeast Asia. The Synergos Institute, New York; http:// www.synergos.org/globalphilanthropy/02/indonesiacsrodirectory.pdf. 2002; Public Interest Research and Advocacy Center (PIRAC) (Indonesia), \& Asian Development Bank. Giving and Fund Raising in Indonesia: Investing in Ourselves. Manila, Philippines: Mandaluyong City, Metro, 2002.

${ }_{17} \mathrm{M}$. Johnson, "Non-government Organizations at the Crossroads in Indonesia", in Rice, R. C. (ed.), Indonesian Economic Development: Approaches, Technology, Small-Scale Textiles, Urban Infrastructure and NGOs, Monash University, Clayton, Victoria: Centre of Southeast Asian Studies, 1990.

${ }^{18}$ The Synergos Institute. National Directory of Civil Society...2002; Feulner, F., "Consolidating Democracy in Indonesia..., 2001; Hasan, S. \& Onyx, J., "Governance Approach in Asia's Third Sector..., 2008.
} 
were a response to the development and industrialization created by the Suharto's government. ${ }^{19}$ As mentioned by Saidi, the impact of modernization projects promoted by the state cannot be handled only by "traditional philanthropy" that mainly focuses on education and health services. ${ }^{20}$ The problem created by industrial development requires different approaches such as advocacy and empowerment programs. Currently, NGOs have focused on issues such as poverty, political participation, empowerment, democracy, environment, and community development. Dana Mitra Lingkungan, for example, has dealt with environmental issues and has successfully mobilized corporate philanthropy to support its programs.

\section{Third phase}

The third phase of the development of third sectors emerged during the "Reformation" era after the downfall of President Suharto. The economic crisis in 1998 followed by the collapse of the New Order regime is identified as a key factor that has encouraged a new phenomenon of philanthropic activities in Indonesia. This period has been marked by the emergence of corporate and religious philanthropic organizations as a response to rising economic crisis and to escalating religious and ethnic conflicts. These philanthropic organizations have utilized domestic resources from individual donations and corporate sectors. ${ }^{21}$

\footnotetext{
${ }^{19}$ Public Interest Research and Advocacy Center (PIRAC) (Indonesia), \& Asian Development Bank. Giving and Fund Raising in Indonesia: Investing in Ourselves. Manila, Philippines: Mandaluyong City, Metro, 2002.

${ }_{20}$ Zaim Saidi, M. Fuad, and H. Abidin, Social Justice Philanthropy in Indonesia, Depok, Indonesia: Piramedia, 2006.

${ }^{21}$ Public Interest Research and Advocacy Center (PIRAC) (Indonesia), \& Asian Development Bank. Giving and Fund Raising in Indonesia: Investing in Ourselves, Manila, Philippines: Mandaluyong City, Metro, 2002.
} 
Among religious philanthropic organizations that have made use of Islamic philanthropy are the Dompet Dhuafa Foundation, the PKPU (the National Humanitarian Foundation) and the Rumah Zakat Indonesia (the Humanitarian and Charitable Foundation). Among corporate philanthropic organizations that have utilized corporate philanthropy are the YMM (affiliated with United Way International) and Dana Mitra Lingkungan (Friends of the Environment Fund). YMM has managed donations from national and multinational companies and has provided grants for smaller NGOs that focus on education and poverty issues. Dana Mitra Lingkungan likewise manages funds from corporate sectors in Indonesia and uses them for dealing with environmental issues.

The great development of religious philanthropic organizations in Indonesia has been influenced by two factors: the first is the support of electronic and print media and the second is good governance. Currently, religious philanthropic organizations have implemented modern management, professionalism, accountability and transparency. This makes them trusted by the general public. Furthermore, this enhancement has marked the movement from "unorganized philanthropy" (traditional philanthropy practiced generally by individuals to other individuals and on several occasions held by religious and social organizations) to "organized philanthropy", although the former is still largely practiced.

The best example of the current phenomenon of "organized philanthropy" can be represented by the Dompet Dhuafa Foundation. This foundation was the brain child of editors and journalists at Republika national daily newspaper who initially collected and managed zakatfunds from the employees of their newspaper company. It quickly grew to collection of funds from broader audiences, newspaper readers and general public. At the same time, the Dompet Dhuafa has utilized a 
corporate model to govern its organization implementing a modern management, professionalism, accountability and transparency. Gradually, the Dompet Dhuafa foundation has been welcomed by the Indonesian people and now has become the largest religious philanthropic organization in Indonesia.

\section{Legal structures, functions, and financial issues of non-profit organizations}

An alternative way of understanding the dynamic of religious non-profit organizations in the context of third sectors in Indonesia is to recognize the legal and functional approach as well as the financial issues that these organizations face.

\section{The legal approach}

There are several laws that regulate nonprofit organizations in Indonesia such as The Foundation (Yayasan) Law No. 16/2001 (then amended by Law No. 28/2004), the Association (Perkumpulan) Law under Indonesian Civil Code (Article 1653), and the Islamic Philanthropic Organizations Law (Zakat Law No. 38/1999 and Wakaf Law No. 23/2004). Most NGOs in Indonesia use foundation as their legal system and a few of them use association. In particular, Islamic philanthropic organizations use foundation as their legal entities, but these organizations are also regulated by Islamic Philanthropy Law (Zakat and Wakaf Law).

The Indonesian government began to regulate Islamic philanthropy several decades ago. The Presidential Decree No. 07/PRINT/10/1968 regulated zakat collection to be the state's responsibility. ${ }^{22}$ As a result, governmental institutions at the province level such as DKI Jakarta and

${ }^{22}$ Alfitri, "The law of Zakat Management and Non-governmental Zakat Collectors in Indonesia", International Journal of Not-for-Profit Law, vol. 8, no. 2 (2006), 55-64. 
West Sumatera started to collect zakat in 1968 and 1973. In the early 1990 s, the success of governmental institutions in collecting and managing Islamic philanthropy became popular, especially in DKI Jakarta branch (the capital city of Indonesia). This success then propelled other social and religious leaders from outside government institution to establish similar philanthropic organizations. Islamic non-governmental philanthropic organizations then mushroomed from the mid of $1990 \mathrm{~s}$ to present. The emergence of these Islamic philanthropic organizations was also a response to economic crisis, natural disaster, and several ethnic conflicts appeared after the collapse of the New Order era in 1998.

These Islamic philanthropic organizations collect and manage individuals' donations, especially zakat and other types of Islamic philanthropy. Religious non-profit organization such as the Dompet Dhuafa Foundation has been more successful than the governmental institutions after ten years of its founding. Now, these religious non-governmental organizations have become strong and independent because they have been benefited from local philanthropy.

\section{The functional approach}

Feulner identifies five functions of NGOs as civil society organizations: (1) mobilizing and pooling interest; (2) monitoring and watchdog; (3) giving legal advice and advocacy; (4) civil society services (education, research, and conflict mediation); and (5) social welfare and healthcare function. ${ }^{23}$ Various secular NGOs in Indonesia have pursued these functions. Various NGOs' programs range from advocacy to service delivery. However, there is a polarization between secular NGOs and reli-

${ }^{23}$ F. Feulner, " Consolidating Democracy in Indonesia: Contributions of Civil Society and State. Part one : Civil Society", Working paper series, Jakarta: UNSFIR, 2001. 
gious NGOs in terms of program areas. Secular NGOs are well known as organizations that focus on advocacy and social change programs such as monitoring, watchdog activism, rights awareness programs, and community development. In contrast, religious NGOs, especially Islamic philanthropic organizations, are well-known for service delivery programs such as education, health, welfare, and relief services. The next discussion will examine the functions of these two types of nonprofit organizations.

\section{The functions of secular NGOs}

Secular NGOs in Indonesia focus on advocacy programs in various areas such as good governance, environment and women's rights. Several NGOs focus on monitoring and watchdog activism such as the Indonesian Corruption Watch (ICW). Several NGOs focus on advocacy such as the Indonesian legal advocacy foundation (YLBH), the health legal foundation (LBH Kesehatan), and the legal advocacy for consumers (YLKI). Other NGOs focus on women's rights such as the Indonesian Women Coalition for Justice (KPI), and the Circle for Alternative Education for Women (KaPal Perempuan). Several NGOs also focus on environmental issues such as the Indonesian Forum for Environment (WALHI), the Indonesia Biodiversity Foundation (KEHATI), and the the Environmental Fund Foundation (DML). Other NGOs such as the Bina Swadaya Foundation and the Mitra Mandiri Foundation focus on training and community development programs. ${ }^{24}$

\footnotetext{
${ }^{24}$ The Synergos Institute.. National Directory of Cvil Society Resource Organizations, Indonesia. Series on Foundation Building in Southeast Asia. The Synergos Institute, New York. http:/ /www.synergos.org/globalphilanthropy/02/indonesiacsrodirectory.pdf. 2002; Zaim Saidi, M. Fuad, and H. Abidin, Social Justice Philanthropy in Indonesia. Depok, Indonesia: Piramedia, 2006.
} 


\section{The function of religious NGOs}

As mentioned above, RNGOs particularly Islamic philanthropic organizations are well-known for service delivery programs such as education, health, welfare, and relief services. Education and health services become the priority programs for RNGOs. These programs aim to empower poor people by giving them a chance to pursue education as a basis for human capital. The Dompet Dhuafa Foundation, for instance, provided 300 scholarships for university students in 2000 with total funds Rp. 1 billion (approx. US $\$ 110,000.00)$. Another foundation, the YDSF, at the same year spent Rp. 16 billion (40\% from total funds) to serve education program and Rp. 182 million to fund the program for orphans. The YDSF also had Foster Parents Program to fund children who were in school age by asking other parents to provide tuition fees for those children. ${ }^{25}$

Some services have been heavily charity-based programs such as basic needs provisions and relief programs. These services include providing food, clothes, shelter, cash assistance, and health/medical services. The Rumah Zakat for example, in 2007 assisted more than a hundred thousand $(118,330)$ free-health services and built four mother and children health clinics. On relief programs, the Rumah Zakat also provided food relief, medical emergencies and education programs for the survivors of earthquake disaster in Yogyakarta in 2006. The PKPU for instance, distributed approximately US $\$ 140,000$ (15.4 billion Indonesian rupiah) for relief program in 2002. On cash assistance, the YDSF provided cash assistance for more than three thousands $(3,628)$

${ }^{25}$ Public Interest Research and Advocacy Center (PIRAC) (Indonesia), \& Asian Development Bank. Giving and Fund Raising in Indonesia: Investing in Ourselves. Manila, Philippines: Mandaluyong City, Metro, 2002. 
poor people with the total approximately US\$170,000 (1,814,073,100 Indonesian Rupiah).

To address welfare issues, these organizations offer micro-finance programs to support small-scale business for farmers, traders, and fishermen. In 2007, the Rumah Zakat supported more than two thousands $(2,063)$ small scale business. The PKPU provided approximately US\$ 40,000 (442 million Indonesian Rupiah) for microfinance programs in 2002.

To date, among Islamic philanthropic organizations, the Dompet Dhuafa Foundation has pursued community development and advocacy programs. This organization has created community development programs to empower several villages that have many poor family members. In 2004, the Dompet Dhuafa has implemented this program to 20 villages, nine villages in cities around Jakarta, and eleven villages across the country. Regarding advocacy programs, this organization has provided advocacy for Indonesian migrant women workers who work in foreign countries. To implement this program, the Dompet Dhuafa staff worked with a worker community in Hongkong and Malaysia. In addition, this organization has also supported widows and women who become heads of households by providing them micro-finance support. ${ }^{26}$

As religious NGOs, Islamic teaching and da'wah programs are one of the organization's main services. Among Islamic philanthropic organizations, the YDSF, the Lazis Muhammadiyah, and the PKPU have provided these religious services to their stakeholders including donors, recipients and general public in order to be more observant Muslims. In addition, the LAZIS Muhammadiyah has supported da'i (preachers) in

${ }^{26}$ A. Fauzia, "Women, Islam, and philanthropy in contemporary Indonesia", in S. Blackburn, B. J. Smith \& S. Syamsiyatun (eds.), "Indonesian Islam in a New Era: How Women Negotiate their Muslim Identities", Monash papers on Southeast Asia, 66; Monash Asia Institute, Clayton, 2008. 
remote areas and the YDSF has supported Islamic school teachers and several mosques.

\section{Financial resources}

The role of international donors for NGOs in Indonesia is central. Several studies mentioned that NGOs have relied heavily on international funding agencies for decades. ${ }^{27}$ According to the Synergos Institute survey, for example, the total revenue of the 25 big NGOs in Indonesia is US\$15.8 million. From that amount, 65 percent (US\$10.3 million) comes from international revenue and only 35 percent (US\$ 5.5 million) comes from domestic revenue. ${ }^{28}$ The primary reason why these funding agencies choose local NGOs is because it is "a cost-effective" and less bureaucratic option for grass roots organizations. ${ }^{29}$

However, international donors are limited and they may stop their assistance. Ibrahim gave an example of an NGO that has very significant influence in Indonesia, the YLBHI (an organization that focuses on law, democracy and human rights). The existence of this organization is now uncertain because two major international donors that once gave financial aid now plan to stop their assistance. This situation will

27 The Synergos Institute.. National Directory of Civil Society Resource Organizations, Indonesia. Series on Foundation Building in Southeast Asia. The Synergos Institute, New York. http:/ /www.synergos.org/globalphilanthropy/02/indonesiacsrodirectory.pdf. 2002; F. Feulner, "Consolidating Democracy in Indonesia: Contributions of Civil Society and State. Part one : Civil Society", Working paper series, UNSFIR, Jakarta, 2001; Hasan, S. \& Onyx, J., "Governance Approach in Asia's Third Sector: Adapted Western or Modified Asian?", in S. Hasan \& J. Onyx (eds.), Comparative Third Sector Governance in Asia. Springer, New York, 2008: 193-205.

${ }^{28}$ The Synergos Institute.. National Directory of Civil Society Resource Organizations, Indonesia. Series on Foundation Building in Southeast Asia. The Synergos Institute, New York. http:/ /www.synergos.org/globalphilanthropy/02/indonesiacsrodirectory.pdf. 2002.

${ }^{29}$ D. Winder, "Civil Society Resources Organizations (CSROs) and Development in Southeast Asia: A Summary of Findings", Series on Foundation Building in Southeast Asia, The Synergos Institute, New York. 1998. 
have a huge impact on YLBHI as they decrease their programs and reduce their staff.

Interestingly, the method of securing financial aid for religious NGOs is diametrically different from secular NGOs. In contrast to outsidefunded secular organizations, religious philanthropic organizations collect and maintain local resources from public donations and corporate sectors in Indonesia. This results in sustainable financial support and public legitimacy.

\section{Conclusion}

Non-profit organizations and philanthropic activities have a long history in Indonesia. This article describes the dynamics of RNGOs in the context of non-profit organizations and civil society development in Indonesia. The dynamics of RNGOs can be seen in their historical development, the legal structures, and the functions of NGOs and RNGOs. While NGOs have mainly focused on social change programs such as advocacy and community development, RNGOs still have been largely implementing charity-based programs. However, in terms of financial resources, RNGOs have benefited from domestic philanthropy while NGOs have benefited from international donor agencies. Previous studies found that NGOs have relied heavily on international donors and these NGOs need to diversify their financial resources from local philanthropy. Therefore, on the one hand, it may help if Islamic philanthropic organizations understand the way the secular NGOs function as civil society organizations; On the other hand, it may also help if secular NGOs learned the way the philanthropic organizations have made use of domestic resources. 


\section{Bibliography}

Alfitri, "The Law of Zakat Management and Non-governmental Zakat Collectors in Indonesia", International Journal of Not-for-Profit Law, Vol. 8, No. 2 (2006): 55-64.

Bamualim, C. S. Islamic Philanthropy \& Social Development in Contemporary Indonesia. Jakarta: Center for the Study of Religion and Culture, State Islamic University Syarif Hidayatullah, 2006.

Berger, J., "Religious NGOs: an Exploratory Analysis", Voluntas, Vol. 14, No. 1 (2003): 15-39.

Candland, C., "Faith as social capital: Religion and community development in Southern Asia", Policy Sciences, 33 (2000): 355-374.

Council of Foundations. United States International Grantmaking: Indonesia. Retrieved on 07/26/2008. Available on line: http:// www.usig.org/countryinfo/indonesia.asp.

Fauzia, Amelia, "Women, Islam, and Philanthropy in Contemporary Indonesia", in Blackburn, S., Smith, B. J., \& Syamsiyatun, S. (eds.). Indonesian Islam in a New Era: How Women Negotiate their Muslim Identities. Monash papers on Southeast Asia, 66. Monash Asia Institute, Clayton, 2008.

Feulner, F., "Consolidating Democracy in Indonesia: Contributions of Civil Society and State. Part one : Civil Society", Working paper series. UNSFIR, Jakarta, 2001.

Hasan, S. \& Onyx, J., "Governance Approach in Asia's Third Sector: Adapted Western or Modified Asian?", in Hasan, S. \& Onyx, J. (eds.). Comparative Third Sector Governance in Asia. Springer, New York, 2008: 193-205.

Johnson, M., "Non-government Organizations at the Crossroads in Indonesia", in Rice, R. C. (ed.). Indonesian Economic Develop- 
ment: Approaches, Technology, Small-Scale Textiles, Urban Infrastructure and NGOs. Victoria: Centre of Southeast Asian Studies, Monash University, Clayton, 1990.

Landim, L. \& Thompson, A., "Non-governmental Organizations and Philanthropy in Latin America: an Overview", Voluntas, Vol. 8, No. 4 (2003): 337-350.

Martens, K., "Mission Impossible? Defining Nongovernmental Organizations", Voluntas, Vol. 13, No. 3 (2002): 271-285.

Public Interest Research and Advocacy Center (PIRAC) (Indonesia), \& Asian Development Bank. Giving and Fund Raising in Indonesia: Investing in Ourselves. Mandaluyong City, Metro Manila, Philippines, 2002.

Priyono, O. S., " Organized Private Philanthropy in Indonesia", in Baron, B. F. (ed.), Philanthropy and the Dynamics of Change in East and Southeast Asia", Occasional papers of the East Asian Institute. Columbia University, New York: East Asian Institute,1991,127-139.

Saidi, Z., Fuad, M., and Abidin, H. Social Justice Philanthropy in Indonesia. Depok: Piramedia, 2006.

The Synergos Institute. 2002. National directory of civil society resource organizations, Indonesia. Series on Foundation Building in Southeast Asia. The Synergos Institute, New York. http:// www.synergos.org/globalphilanthropy/02/indonesiacsrodirectory.pdf.

Winder, D. Civil Society Resources Organizations (CSROs) and Development in Southeast Asia", A summary of findings. Series on Foundation Building in Southeast Asia, The Synergos Institute, New York, 1998. 